\title{
ANTECEDENTS OF CONSUMER BUYING INTENTION ON THE PRODUCTS OF HIJAB SMES IN GRESIK
}

\author{
Surjanti JUN ${ }^{1 *}$ \\ Soesatyo YOYOK ${ }^{2}$ \\ SANAJI ${ }^{3}$ \\ Wibawa Setya CHENDRA ${ }^{4}$
}

Received: July 2019 | Accepted: February 2020 | Published: April 2020

Please cite this paper as: Jun, S. et. al. (2020). Antecedents of Consumer Buying Intention on the Products of Hijab SMEs in Gresik, Holistica Journal of Business and Public Administration, vol. 11, iss. 1 , pp. 1-12

\begin{abstract}
Consumers are important factors that must be considered by business actors because they are one of the determinants of business sustainability. There are several causes to trigger customer buying intention, such as product types, trademarks, and prices. This study aims to determine the antecedent of consumer buying intentions of Hijab SMEs products from Gresik. This study uses a quantitative approach with explanatory research using correlation research design survey. The respondents were 75 consumers from 7 Hijab SMEs Gresik. The results indicate that factors related to the emergence of consumer buying intentions for Hijab SMEs products are raw material (fabric), stitches, designs, and price

Keywords: Hijab SMEs; consumer buying intention
\end{abstract}

\section{Introduction}

A business that is either a service or a product will not be separated from the presence of consumers. Consumers become an important factor that must be considered by business people in making policies. This is because consumers will also determine the sustainability of a business. In terminology, consumers mean someone or organization that uses commodities or services. Whereas in economic terms, it means someone or organization

\footnotetext{
${ }^{1}$ Department of Economic Education, Faculty of Economics, University of Negeri Surabaya, Indonesia, junsurjanti@unesa.ac.id

${ }^{2}$ Department of Economic Education, Faculty of Economics, University of Negeri, Surabaya, Indonesia

${ }^{3}$ Department of Management, Faculty of Economics, University of Negeri Surabaya, Indonesia

${ }^{4}$ Technical Faculty, University of Negeri Surabaya, Indonesia

*Corresponding author
} 
that uses commodities or services. In addition, in the marketing business, consumers are people or organizations that buy products or services. This term also refers to the employment of goods and services including humans or other economic entities that use goods or services. In addition, they do not sell the items they buy. They are end users in the distribution chain of goods and services. In fact, sometimes consumers may not be buyers. For example, small children are end users of toys, but their parents buy them. Therefore, in the toy market, buyers and consumers are often different people. Leonard mentions in his writing that consumers are individuals who buy products or services for personal use and not for making or reselling, they can make a decision to buy an item and someone who can be influenced by marketing and advertising.

Before studying about consumer buying intentions, firstly, we should understand consumer habits/behavior because without knowing their behavior/habits, business actors will find it difficult to map their intentions. Consumer behavior is simply defined as the study of psychological, social and physical actions when people buy, use and dispose of products, ideas, services, and practices (Peter \& Olson, 2008). They also explained that consumer behavior consists of ideas, feelings, experiences with additional environmental factors such as prices, praise, and advertising. In addition, consumer behavior is also considered a dynamic process because ideas, perceptions, and activities of consumers as individuals or groups can change continuously. While according to Solomon (2006) consumer behavior is defined as a decision-making process and physical activity involved in acquiring, evaluating, using, and disposing of goods and services to meet needs and desires.

Likewise, Belch \& Belch (2001) argued that consumer behavior as a process and activity of people involved when looking to choose, buy, use, evaluate and dispose of products and services as if meeting their needs and desires. In his research, Blackwell et al. (1978) in Chandron (2013) state that the basic idea behind consumer research is to question the reason for purchasing, moreover, researchers have to be profound and also should ask people how and where the state of purchase and consumption. Understanding the consumers' needs and desires, perceptions, motivations, emotions, as well as attitudes to lead in purchasing decisions becomes a prerequisite condition to perceive consumer behavior (Sheth, 2014).

Islamic fashion products such as clothing, accessories, and hijab (veil) influenced by the Islamic fashion product market have significant growth and high demand for Muslim consumers from around the world. Thus, fashion designers, manufacturers, retailers, and fashion online stores are preferred to have more opportunities in developing their market (Win \& Jan, 2017). Farida and Hati (2017) state that marketing strategies are very important for their customers' purchase intentions. This study is in line with Farida and Hati's study in discovering the phenomenon of hijab in Indonesia. They found that the marketing mix strategy had an effect on purchase intention. In addition, different companies have different customer buying intentions (Farida \& Hati, 2017). Liu (2013) states that conscious consumers are risk averse and this awareness drives their behavior to buy a product. While Akbari, Gholizadeh and Zommorodi (2014) argue that when one 
HOLISTICA Vol 11, Issue 1, 2020, pp. 1-12

sees that religious symbols or beliefs in the package of goods offered, the desire to buy these items will strengthen. Referring to this condition, Kanesan and Krishnan (2018) mentions that the main segmentation in "Hijabista" is geographical, demographic, psychographic, and behavioral.

Fashionable hijab is inseparable not only from the type of fabric that is used but also further led to fashion. Latiff and Alam (2013) state that even the media is involved in the spread of the Hijab style. The media commercialized hijab clothing to move forward in the fashion line. In order to survive in the industry because there are so many competitors, business providers must focus on the needs and preferences of customers to maintain and maintain long-term relationships, then customers must be satisfied, business providers must know the elements in the marketing mix they need to practice customers primarily through their buying behavior (Fadhilla, 2017). This is also to meet the demands of the world market for hijab products. In Malaysia, the demand for fashion headscarves is now growing due to fashionability that fits the lifestyle of today's modern customers (Delaila, Aziz, \& Ariffin, 2016). With the changing lifestyles of Malaysian Muslim consumers, awareness of appearance, beauty, and care, Muslim consumers, in particular, women are more likely to buy hijab that match their feminine ideals such as feminine, chic and versatile.

SMEs are a type of industrial entity grouped into small and medium levels because of the amount of capital and workers. Hijab SMEs Gresik is one type of fashion SMEs in Gresik. Hijab SMEs developed in Gresik have women as a majority of business actors. In its business activities, hijab SMEs have carried out synergies of cooperation both in internal and external production so as to be able to form high industrial potential. Hijab SMEs Gresik's products not only are available in the regional market but also reach the national market and, further, expanded to the foreign market. However, because there are shortcomings in maximizing business activities, the potential of this Hijab SMEs cannot yet develop optimally. One of the optimizations of the potential of the Hijab Gresik UKM can be seen from the instability of product quality (stitching) and designs that have not been able to answer the wishes of modern markets widely (Diskoperindagkop Kabupaten Gresik, 2014).

This study aims to analyze and determine factors influencing consumer buying intention on products of Hijab SMEs Gresik. Thus, the results would be able to serve as reference for future related studies as well as for policy makers in order to create appropriate policy which is able to help in developing SMEs. Significantly, this study can be used to generally understanding the shortcoming of hijab SMEs in Gresik, specifically, and to create overall view for how the SMEs should overcome the factors which may lead to their business declines. 


\section{Literature review}

\subsection{Hijab Industry}

Hijab is fashion accessoris that is usually used by Muslim women to cover their hair and neck. Different cultural and religious backgrounds affect hijab designs such as sizes, styles, and colors. Unlike other fashion, hijab can identify the wearer's identity (Monkebayeva, et. al., 2013). Ethnicity, culture, region, or tribe will give a special characteristic on its design. Thus, hijab can also be an indicator to depict certain culture or region; for examples 'kerudung' is from Indonesia and Malaysia; 'abaya' is from Saudi Arabia; 'chador' is from Iran; 'burqa' is from Afghanistan; 'niqab' is from India; 'purdah' is from Pakistan; and 'buibui' is from East Africa (Nastor, 2017).Along with the growing modernized era, hijab is no longer used as a set of Muslim clothing, but it emerges with additional value as an opportunity for new fashion trends. As seen from young modern Muslim women, they wear hijab to show their cool and fashionable attitudes in which representing their modern life. This behavior and thought push hijab into new limelight as a part of fashion industry.

Various aspects affect the development of a hijab industry in a country, for example the number of Muslim residents who reside, government policies, original culture, and technological and economic developments. As happened in Iran, due to the Iran Islamic government policy in promoting certain types of textiles, the development of hijab fashion in Iran follows these conditions. Therefore, materials used as raw material for hijab tend to incline to textiles promoted by the government (Turan \& Kanat, 2006). As part of the textile industry, hijab industry opens an opportunity to advance the economy on society and nation. However, to achieve this condition, the nation or hijab industry specifically, has to be able to answer the demands in terms of product quality (design, materials, etc.), quantity, and price. As in Iran, even though it is a hijab producer, due to government policies that limit the development of textile industry, Iran is 'failing' to achieve 'good' state on the world's economy, especially in the textile industry (Turan \& Kanat, 2006). Therefore, in order to support the development of hijab industry, aspects that correlate to its development should be carefully prepared and dealt.

A competitive advantage is a capability of a firm to create more economic value than competitors (Peteraf \& Barney, 2013) and "the degree to which a firm has exploited opportunities, neutralized threats and reduced costs" (Newbert, 2008, p. 752).

Scholars have pointed out that it is necessary to distinguish between a corporate competitive advantage and corporate performance (Sigalas, et al., 2013; Powell, 2001). Sigalas et al. (2013) argued that a competitive advantage means competitiveness above average in the same industry, while a superb performance of a firm indicates a performance above average in the same industry. Newbert (2008) suggests that there is a positive correlation between obtaining a competitive advantage and a firm's outstanding performance. In other words, a firm's performance is a parameter measuring a competitive advantage so that if a firm has a competitive advantage, it comes out in a firm's performance (Newbert, 2008; O'Shannassy, 2008; Powell, 2001). 
HOLISTICA Vol 11, Issue 1, 2020, pp. 1-12

Porter (1980) argues that firms have to add greater value to their products and services than competitors and make their supply chains support their general strategy. Also, he pointed out that firms do not "stuck in the middle", firms establishing and maintaining a clear generic position in their product market can obtain competitive advantages. On the other hand, a resource-based view, learning theory, and core competence theory explain that a sustainable competitive advantage is created by a value-creating strategy that cannot be imitated by competitors (Barney, 1991). The value and rareness of resource holding firms are crucial factors of a sustainable competitive advantage (O'Shannassy, 2008).

To obtain a corporate competitive advantage, firms choose vertical integration and diversification strategies, mergers \& acquisitions (M\&A), and strategic alliances as firmlevel strategies (Barney, 2011). In particular, competition among firms has been changed from firm-level competition to group-level competition (Gomes-Casseres, 2003; Morrish \& Hamilton, 2002; Ireland et al., 2002; Whipple \& Frankel, 2000) as a tool ensuring a competitive advantage, strategic alliances have attracted attention. In the next section, this research discusses international airline alliances.

\subsection{Characteristics of Hijab SMEs Industry in Gresik Regency}

Hijab SMEs industry in Gresik Regency has its own characteristics compared to other SMEs. From the data mapping carried out by the researchers, there are three materials used in the production of 7 SMEs in this study, including t-shirt, chiffon, and crepe fabrics. From the model aspect, according to the data collected from the SMEs, there are a few models that are used, namely: sharia, mermaid, pasmina, robbani, pinquin, khimar, standards, and kids-friendly.

The characteristics of the stitches are mostly produced using high speed sewing machine with obras and neci. Compared to other SMEs such as in Bangil and its surrounding, the result of these SMEs' fabrics are smoother. The price of the product at the wholesale level for t-shirt fabric ranges from Rp15.000 to Rp40.000, chiffon fabric ranges from Rp21.500 to Rp60.000, and crepe fabric ranges from Rp25.000 to Rp50.000. From the price aspects, the Hijab SMEs industry in Gresik Regency has the advantages.

\subsection{Threat of Asia Economic Community on Hijab SMEs in Gresik}

Hijab industry as a variety of local wisdom has its difficulties and challenges in order to survive in the global trade. Local wisdom is local potential defined as natural, human, technological, and cultural resources of an area (Hariyadi, 2010; Vanclay, 2011; Aditiawati, et al., 2016). Whereas local wisdom is defined as knowledge gained from experience and passed down from generation to generation or a life view, knowledge and life strategy (Alfian, 2013; Akhmar \& Syarifudin, 2007; Phongphit \& Nantasuwan, 2002; Kongprasetamon, 2007). Local wisdom in Gresik Regency is called "The City of Santri" (Rosidin, 2015). Proves of the potential for local wisdom in the human resource aspect are shown by the ability of craftsmen in the hijab industry to work by holding the values of Islamic life, selecting the work types, as well as the hereditary sewing skills, while Local 
wisdom in the aspect of production is characterized by the type of product itself, namely the syari hijab which has an Islamic nuance and strengthens the local wisdom of Gresik as the City of Santri.

Hijab SMEs in Gresik have their own characteristics compared to other SMEs, especially on the system built. Mostly, hijab SMEs are a single business entity, yet the production process in the hijab SMEs in Gresik is actually divided and depends on craft units outside the main SMEs business unit. The main SMEs have a function as product collectors from hijab producers and another is craftsmen who are the producers of hijab in Gresik. In this study, the focus of hijab SMEs studied was in Banyuwangi district, Manyar Sido Rukun district, and Manyar Rejo district. The relationship between the main SMEs and craftsmen has existed and become decades of tradition. The above conditions indicate that the main SMEs have a large role in the management of hijab business resources in Gresik. Main SMEs have a large multiplier effect for the sustainability of the livelihoods of the surrounding residents.

\subsection{Consumer Buying Intention}

In identifying and satisfying the consumers' needs and desires, it is important to recognize the value of each consumer's role. Once ignored, it is very likely that the consumer will disappear. There are three main things should be considered to fulfill consumer desires so it will ignite one' intention to buy/use the products (Sheth, 2014). First is product design. The design includes features that have to be available and sought by users. Second is price. Payers play an important role because if the price or other financial considerations do not satisfy the payer, the transaction will not be carried out. However, the purchaser is not always consumer. Last is access to products. For the consumer, access to buy products is one of the factors that determine consumer buying intention because even though the quality and price are acceptable, when the access to buy the product is difficult, then the buying intention will relatively decrease.

Buying intention is one of the most important concepts in consumer behavior studies. Every year marketers spend billions of dollars in advertising just to influence buying intentions. By influencing consumer buying intentions, marketers hope to influence their buying behavior (Arnould, et al. 2002). Buying intention is an important aspect to evaluate consumer behavior in buying goods. According to Spears \& Singh (2004), purchase intention can be defined as a person's conscious mind to buy a certain item. In addition, Schiffman and Kanuk (2000) argues that if the intention to buy a product increases, it will affect the consumer's desire to buy the product.

Consumer buying intention leads to purchasing decisions. But it is not an immediate step, yet there are several considerations taken (Surjanti, 2009). Ferrel et al. (1995) stated that the process of purchasing decisions taken by customers includes knowing the problem, seeking information, evaluating alternatives, and evaluating purchases and postpurchases. Knowing the problem includes an analysis of certain product needs followed by information searching through certain sources. After the product is found, the consumer evaluates alternatives to compare the product before it is purchased, then 
HOLISTICA Vol 11, Issue 1, 2020, pp. 1-12

decides to buy and the last is evaluating the product fully Knowledge is information stored in memory According to Blackwell et al. (1994), customer knowledge consists of three majors, namely product knowledge, purchasing knowledge, and usage knowledge. Knowledge usage includes available information about how a product is used and what is needed to be used. In buying products, consumers will pay attention to product characteristics, which consist of product attributes. Furthermore, consumers observe the consequences or effects that arise from the product (such as product functions and psychosocial values of product use) (Surjanti, 2009).

\section{Method}

This study uses a quantitative approach of explanatory research. The design is correlation research in order to look for the antecedent of consumer buying intention on Hijab SMEs products from Gresik. This study analyzed four independent variables, namely fabric (factors A), stitches (factor B), designs (factor C), and price (factor D). Those were selected because of their positively and significantly affect consumer buying intention. The population was a group of young consumers who purchased hijab produced by Hijab SMEs in Gresik. There were 75 respondents who were the consumers of 7 Hijab SMEs in Gresik. Data were analyzed using multiple regressions with the classical assumption test.

\section{Result and Discussion}

\subsection{Respondents Characteristics}

To select respondents, researchers defined consumers into criteria: those who bought hijab using three types of fabrics. From the questionaires, data were grouped into: age; background of study; financial capability; and physical appearance. Data indicate that most of consumers were young (19-22 years old), undergraduate students, financially capable (middle-high), and physically good/well-shaped.

\subsection{Factors Analysis}

There are five factors analyzed in this study, namely: consumer buying intention, fabric, stitches, design, and price. To address issues relating factors influencing consumer buying intention on products of Hijab SMEs in Gresik, regression test was employed. Five factor selected previously are used as dependent variables. Exploratory analysis on indicators of each factor was conducted in order to determine new variable which was unrelated to high correlation among variables. The procedures were 1) total factor determined by eigenvalue $>1$ meaning that only factor with eigenvalue $>1$ included in analysis; 2 ) extraction method using PCA (Principle Component Analysis;3) rotation method usingvarimax rotation.

The results of factors analysis were used for data reduction. Malhotra (2007) mentioned that feasibility needs to be tested by measuring the sampling appropriateness (Uji KMO 
HOLISTICA Vol 11, Issue 1, 2020, pp. 1-12

and Bartlett's Test of Sphericity) as well as its capability to explain data origin (Average Variance Extracted - AVE). Recommended by Hair et al. (2009), KMO should be equally or higher than $0.50(\geq 0.50)$ and with significant of 0.05 using Bartlett's Test of Sphericity to determine the feasibility of factor analysis.

Table 1 Feasibility of Factor Analysis

\begin{tabular}{|c|c|c|}
\hline Indicator of feasibility & Result & Conclusion \\
\hline $\begin{array}{l}\text { Kaiser-Meyer-Olkin Measure of Sampling } \\
\text { Adequacy. }\end{array}$ & 0.880 & $\begin{array}{c}\text { Factor } \\
\text { analysis is }\end{array}$ \\
\hline $\begin{array}{l}\text { Bartlett's Test of Sphericity (Approx. Chi- } \\
\text { Square }=1309.143 ; \mathrm{df}=136 \text { ) }\end{array}$ & Sig. $=0.000$ & $\begin{array}{l}\text { feasible for } \\
\text { data }\end{array}$ \\
\hline Average Variance Extracted (AVE) & $82.35 \%$ & reduction \\
\hline
\end{tabular}

Source: SPSS attachment

From the factor analysis test, KMO (Kaiser-Meyer-Olkin) value was 0.880 or higher than 0.50. It indicates that KMO test met the standard required. Similarly for Bartlett's Test of Sphericity, it shows the significance of 0.05 . Further, factor analyses were able to reduce 17 variable origin (total indicators of five factors) into four new factor with higher degree of capability indicated by the AVE value of $82.35 \%$ meaning that four factors generated were able to explain the variety of data origin.

From KMO test, Bartlett's Test of Sphericity, and AVE, factors analyses can be further explored as they have high capability to explain the variety of data origin. Each factor contributed to explain the data variation as: factor A as $24.97 \%$,factor Bas $19.96 \%$,factor C as $19.96 \%$, factor $D$ as $19.48 \%$, and factor $E$ as $17.94 \%$. Afterward, the factors obtained were interpreted by naming each of them, as suggested by Maholtra (2009), usingsurrogate variable.

Based on variables in generated factors, four factors were named into factor 1 = fabric (X1), factor 2 = design (X2), factor 3 = stitches (X3), and factor $4=$ price (X4). In addition, those four variables were used as independent variable to determine the consumer buying intention (Y) on hijab. As those were resulted from factor analyses, value of each variable was represented by factor score, a standardized score to estimate the factor quality of each variable origin.

Table2 Results on Factor Analysis

\begin{tabular}{ccccccc}
\hline Factor & Variable origin & \multicolumn{4}{c}{ Factor loadings } & \multirow{2}{*}{$\begin{array}{c}\text { \% of } \\
\text { Variance }\end{array}$} \\
\cline { 3 - 6 } & & 1 & 2 & 3 & 4 & \\
\hline \multirow{2}{*}{ Factor1 } & Fabric 2 & 0.905 & 0.083 & 0.053 & 0.030 & \\
(Quality & Fabric 1 & 0.814 & 0.139 & 0.205 & 0.156 & \\
of & Fabric 4 & 0.778 & 0.325 & 0.160 & 0.217 & 24.970 \\
Fabric) & Fabric 5 & 0.759 & 0.164 & 0.165 & 0.282 & \\
& Fabric 3 & 0.691 & 0.375 & 0.121 & 0.121 & \\
Factor2 & Design 2 & 0.214 & 0.845 & 0.217 & 0.261 & \\
(Design) & Design 1 & 0.169 & 0.845 & 0.241 & 0.090 & 19.958
\end{tabular}


HOLISTICA Vol 11, Issue 1, 2020, pp. 1-12

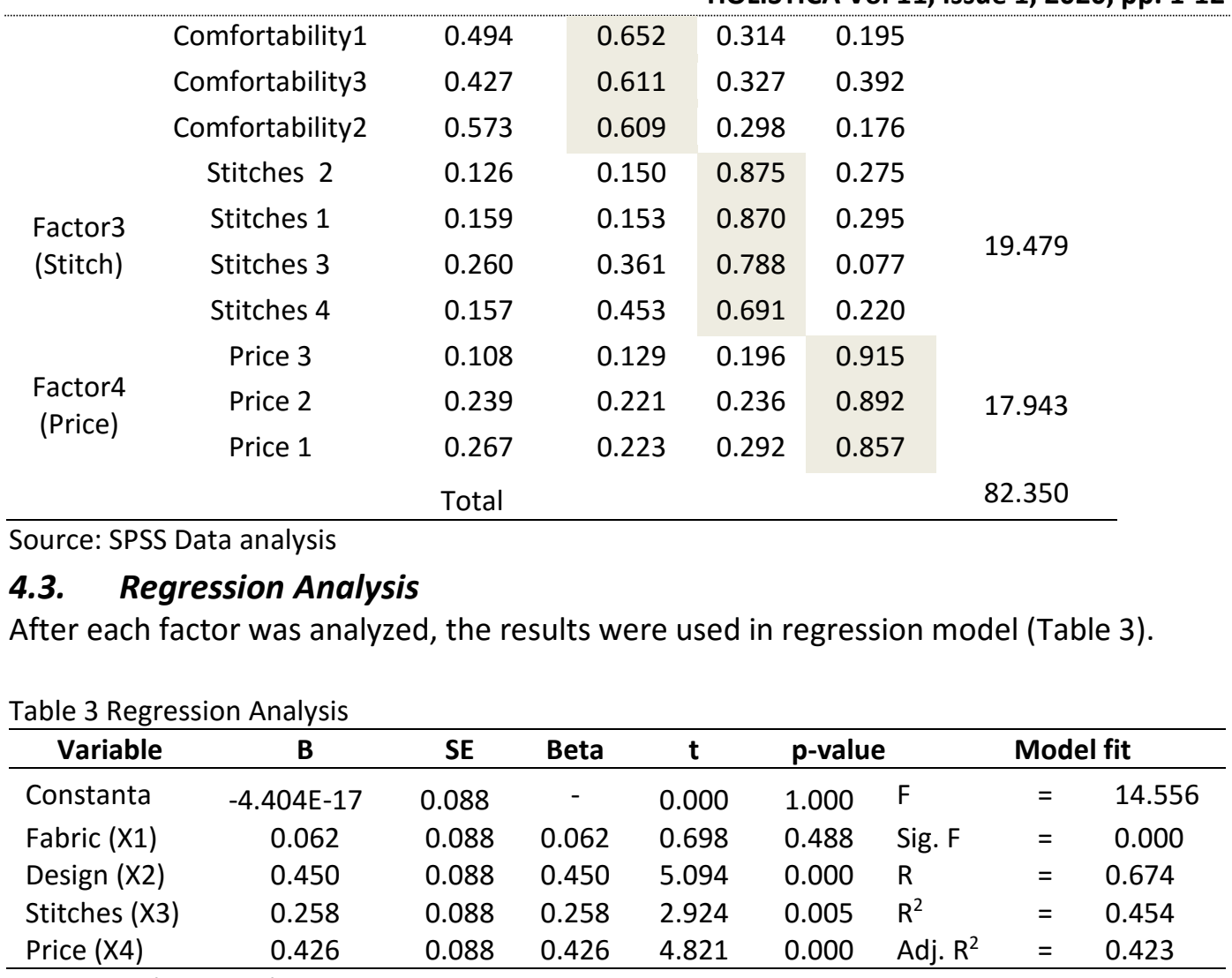

Source: Authors results

From factor analysis data, multiple regression model was formulated as:

$Y=-4,404 E-17+0,062 X 1+0,450 X 2+0,258 X 3+0,426 X 5+e$

Significance testing on the influence of independent variables has an error tolerance of (alpha) 5\%. It means that independent variable has a significant influence on consumer buying intention if pvalue is less than $0.05(<0.05)$. Accordingly, the results show that: 1$)$ fabric has tcountas 0.698 with a significance of $0.488 ; 2$ ) design has tcount as 5.094 with a significance of 0,$000 ; 3$ ) stitching quality has tcountas 2.924 with a significance of 0.005 , and price has tcountas 4.821 with significance of 0.000 . Among four, only fabric has a significance higher than 0.05 (>0.05), while the other three has a significance of 0.000 meaning that it is less than $0.05(<0.05)$. Hence, only fabric that does not significantly influence consumer buying intention $(p=0.488, p>0.05)$, while the remaining three significantly influence consumer buying intention $(p=0.000, p<0.05)$.

Based on multiple regression analysis, it is concluded that the factors significantly affect consumer buying intention of products from Gresik Hijab SMEs are design, stitches, and price. In addition, from t count, it indicates that design has a higher influence than both stitches and price. Related to the regression test, in design, comfortability is one of the indicators that presumably determine the consumer buying intention. 
Moreover, the regression results need to tested for its feasibility, whether it is possibly used to predict the in the dependent variable. The feasibility test is seen from the significant $F$ count and the magnitude of the coefficient of determination. From the analysis, it shows that Fcount is 14.556 with a significant 0,000 meaning that fabric (X1); design (X2); stitches (X3); and price (X4) can be used together to determine consumer buying intentions. The ability to predict consumer buying intention is $42.3 \%$ indicated by Adjusted R2 of 0.423 . Meanwhile, the remaining $57.7 \%$ is due to unexamined factors in this study. The value of Adjusted R2 of $42.3 \%$ is categorized as moderate or adequate in the model feasibility.

\section{Discussion}

The result of this study supports Solomon (2006); Belch \& Belch (2001) which showed that in hijab product, consumer behavior involves evaluation in giving consideration for the materials, models, stitches, and prices to fulfill their needs in hijab. In accordance with Chandron (2013), buyers also conduct consumer research on themselves and from the data obtained from others. According to Sheth (2014), they even involve their emotion in making a purchase decision. It needs to be explored, considering that according to Win and Jan (2017) and Delaila, Aziz and Ariffin (2016)fashion is a market of mode that is currently developing and must be adjusted to lifestyle and trend. In line with the study from Farida \& Hati (2017), hijab is one of the fashion products that develops in Indonesia. It is strengthened by Sedang Akbari, Gholizadeh and Zommorodi (2014); Latiff and Alam (2013); Latiff and Alam (2013) that religious symbol or strong basic beliefs offer goods that can be commercialized. However, Kanesan and Krishnan (2018) have seen the relationship between geographic, demographic, psychographic, and behavioral aspect in "Hijaberista", a hijab lovers and users who follow the hijab fashion that can be commercialized. It has to be maintained in a long-term, therefore the research about consumer behavior is required (Fadhilla, 2017).

Based on the interview, it is found that from the material aspect, hijab tends to follow the trend, which is ceruty fabric. The materials used by SMEs are also chosen accordin to the trend, such as stella, crepe, and ceruty fabric. One of the observer who works in hijab design industry named Ani stated, "This is cheap, but still good... surely for the materials and models, but the stitches is good enough, although it must be fixed...". From the price aspect, one of the employee of the 7 SMEs stated, "The price of my hijab product starts at Rp280.000 for 20 pieces, and for the ceruty fabric the price starts at Rp1.400.000 for 20 pieces." From the opinion of the researchers who are also hijab users and lovers, the price is very cheap and competitive, and suitable with the material.

\section{Conclusion and Suggestion}

From data analysis, this study was able to formulate the model of antecedents on consumer buying intention (Y) from factors analyzed, namely fabric (X1), design (X2), 
stitches (X3), and price (X4) asY $=-4,404 E-17+0,062 X 1+0,450 X 2+0,258 X 3+0,426 X 5+$ e. Feasibility test indicates that design (X2), stitches (X3), and price (X4) significantly influence to consumer buying intention $(Y)$. Therefore, the better design, stitches, and price offer, the higher consumer buying intention is formed/ triggered. Here is seen from the Adjusted R Squareas0.423 meaning that design, stitches, and price are highly possibly to calculate the consumer buying intention, while the raw material (fabric)did not significantly indicate the consumer buying intention, as it is possibly because most of material (fabric) used in hijab industry are similar (from same types of textiles). For future studies, this study can be used as reference on how to develop the hijab SMEs in Gresik specificallly - and for other researches/studies on consumer buying intention - generally.

\section{Acknowledgement}

This research was funded by DRPM Ditjen Penguatan Risbang, Skim Penelitian Strategis Nasional Hibah Institusi, RistekDikti Indonesia through LPPM Universitas Negeri Surabaya.

\section{References}

Akbari, M., Gholizadeh, M., \& Zommorodi, M. (2014). Purchase intention of product with Islamic labels under time pressure, Marketing and Branding Research, 1: 14-26.

Alnsour, M. (2018). Social Media Effect On Purchase Intention: Jordanian Airline Industry, Journal of Internet Banking and Commerce. 23(2).

Arnould, E.J., Price, L.L., \& Zinkhan, G.M. (2002), Consumers, $2^{\text {nd }}$ ed. New York: McGraw-Hill.

Belch, G. E. \& Belch, M.A. (2001). Advertising \& Promotion: An Integrated Marketing. Communication Perspective. New York: McGraw Hill

Blackwell, R. D., Engel, J.F., \& Kollat, D. T. (1978). in Chandron, R. (2013). Consumer Behavior. Journal of Advertising, 8 (1): 52-53, DOI: 10.1080/00913367.1979.10673276.

Blackwell, R.D., Engel, J. F., \& Milliard, P. W. (1994). Prilaku Konsumen, Alih Bahasa FX Budiyanto. Penerbit Binarupa Aksara: Jakarta.

Carù, A., \& Cova, B.. (2003). A Critical Approach To Experiential Consumption: Fighting Against The Disappearance of The Contemplative Time, Stream 23: Critical Marketing: Visibility, Inclusivity,

Captivity. https://www.mngt.waikato.ac.nz/ejrot/cmsconference/2003/proceedings/criticalmarketi ng/Caru.pdf

Chiu, C. (2009). Understanding relationship quality and online purchase intention in e-tourism : A qualitative application, 669-675. http://doi.org/10.1007/s11135-007-9147-6

Delaila, Z., Aziz, A., \& Ariffin, S. (2016). Factors Influencing Brand Loyalty toward Fashion Hijabs : A Conceptual Paper. International Academic Research Journal of Business and Technology, 2(2), 194-198.

Essays, UK. (November 2018). Meaning and Definition of Consumer Behaviour. Retrieved from https://www.ukessays.com/essays/marketing/meaning-and-definition-of-consumerbehaviour-marketing-essay.php?vref=1

Fadhilla, F. (2017). The Effect of Hijab Fashion Company Marketing Mix Strategy to The Number of HIJAB Consumer in Indonesia, International Journal of Management and Applied Science (IJMAS), Vol.3, Iss.8: 16-20.

Farida, H., \& Hati, Sr. R. H. (2017). Hijab Fashion Consciousness and Consumption Among Generations $X$ and Y. Advances in Economics, Business and Management Research (AEBMR), 
2nd International Conference on Financial Innovation and Economic Development (ICFIED 2017). http://doi.org/10.2991/icfied-17.2017.37

Ferrell, P. \& William, M. P. (1995). Pemasaran: Teori \& Praktik Sehari-hari Edisi Ketujuh, Alih Bahasa Drs. Daniel Wirajaya, Jakarta:Bina Aksara.

Grine, F., \& Saeed, M. (2017). Is Hijab a fashion statement? A study of Malaysian Muslim women. Journal of Islamic Marketing, 8(3): 430-443. http://doi.org/10.1108/JIMA-04-2015-0029

Kanesan, S., \& Krishnan, K. (2018). An Analysis of Market Segmentation ( Naelofar Hijab 's Brand). International Journal of Business and Management Invention (IJBMI), 7(4): 81-85.

Latiff, Z. A., \& Alam, F. N. S. Z. (2013). The Roles of Media in Influencing Women Wearing Hijab: An Analysis. Journal of Image and Graphics, 1(1): 50-54. http://doi.org/10.12720/joig.1.1.5054

Leonard, K. (nd). Customer and Consumer Definitions.Small Business - Chron.com. http://smallbusiness.chron.com/customer-consumer-definitions-5048.html. Accessed on 06 February 2019.

Monkebayeva, K.Zh., Baitenova, N.Zh., \& Mustafayeva, A.A. (2013). History of Appearance and Distribution of Hijab and its Types, Proceedings of World Academy of Science, Engineering and Technology, no. 71: 1360.

Nistor, L. (2017). Hijab(istas) - as Fashion Phenomenon. A Review, Acta Universitatis Sapientiae Social Analysis. 7. 10.1515/aussoc-2017-0004.

Peter, J. P., \& Olson, J. C. (2008). Consumer behavior and marketing strategy (8th ed.). Singapore: McGraw-Hill.

Schiffman, L. G. \& Kanuk, L. L. (2000). Consumer Behavior, 8th edition. Wisconsin: Prentice Hall,.

Sheth, Jagdish. (2014). Consumer Behavior. https://www.researchgate.net/publication/238748265_Consumer_Behavior

Singh, G. \& Singh, I. \& Vij, S. (2017). Antecedents and Consequences of Customer Loyalty: A Conceptual Model. International Journal of Applied Business and Economic Research. Vol 15: 237-251.

Solomon, M., Bamossy, G. J., Askegaard, S., \& Hogg, M. K. (2006). Consumer Behaviour: A European Perspective (3rd Edition). London: Prentice Hall.

Spears N., \& Singh, S. N. (2004). Measuring Attitude Toward the Brand and Purchase Intentions. Journal of Current Issues \& Research in Advertising, Vol. 26 No. 2, http://www.ljemail.org/reference/References Papers.aspx?ReferencelD=1639605 Accessed on April 21th 2019 Pp. 53-56

Surjanti, J., Batan, I. M. L., Anneke, E. K., \& Budiono, A. P. (2009). Embroidery Product Characteristics Analysis Based on Customer Satisfaction as a Trial Project for Empowering SMEs in East Java (Case Study in Embroidery SMEs in Sidoarjo). The International Journal of Accounting and Business Society.Vol. 17, No.1/ Agustus 2009

Thusyanthy, V., \& Tharanikaran, V. (2017). Antecedents and Outcomes of Customer Satisfaction: A Comprehensive Review. International Journal of Business and Management. 12: 144. 10.5539/ijbm.v12n4p144

Turan, A. (2006). The effects of the textile and clothing sector on the economy of Turkey. Fibres and Textiles in Eastern 16-20. https://www.researchgate.net/publication/296856722

Wilson, J. A.J., Belk, R. W., Bamossy, G.J., Sandikci, Ö., Kartajaya, H., Sobh, R., Liu, J., \& Scotts, L. (2013). Crescent marketing, Muslim geographies and brand Islam: Reflections from the JIMA Senior Advisory Board.Journal of Islamic Marketing, Vol. 4 (1): 22-50, https://doi.org/10.1108/1759083131130633

Win, H. T., \& Jan, M. T. (2017). Muslim Consumers ' Online Purchase Intention towards Islamic Fashion Products : A Clothing Market Case, 1(2): 72-81.

https://marketbusinessnews.com/financial-glossary/consumers-definition-meaning/ 